http:/ / dx.doi.org/10.30747/bfgez.67.2017.06

\title{
WARTE PRZECZYTANIA
}

Sophie Hodorowicz Knab, Naznaczone litera "P”. Polki jako robotnice przymusowe w III Rzeszy 1939-1945, Wydawnictwo Literackie, Warszawa 2018, ss. 491, ISBN 978-83-08-06570-9

W czasie II wojny światowej robotnicy przymusowi stanowili jeden z najważniejszych filarów gospodarki wojennej Niemiec. Pochodzący z okupowanych krajów dorośli i dzieci, traktowani niczym zdobycz wojenna, mieli obowiązek rejestracji w odpowiednich urzędach, celem skierowania ich do niewolniczej pracy w przemyśle i rolnictwie. Pozbawiano ich praw, odpowiednio znakowano, izolowano i przetrzymywano w dramatycznych warunkach, wyzyskiwano. Rzekome przewinienia czy ucieczkę z miejsca pracy karano grzywną, uwięzieniem w obozie koncentracyjnym, innymi represjami (także w stosunku do ich rodzin) a nawet śmiercią. Ponad połowę polskich robotników przymusowych w Niem-

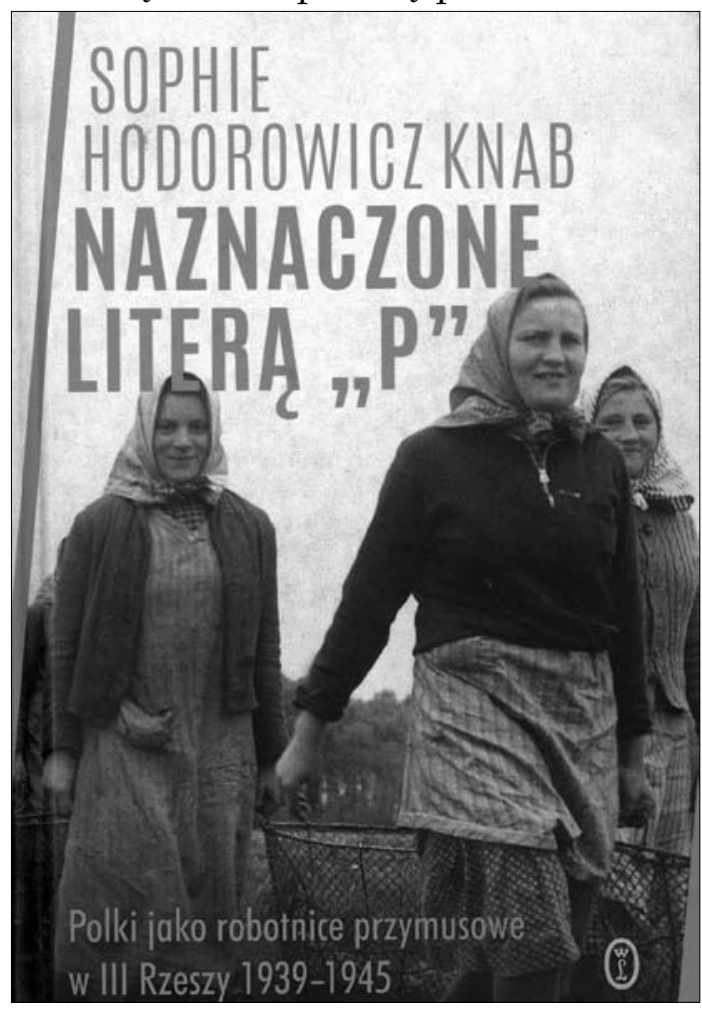
czech stanowiły kobiety około dwudziestego roku życia. Pierwszą próbą całościowego ukazania ich losów jest książka pt. Naznaczone literg "P”. Polki jako robotnice przymusowe w III Rzeszy 1939-1945, Sophie Hodorowicz Knab.

Jej autorka jest amerykanką o polskich korzeniach, urodzoną $\mathrm{w}$ jednym $\mathrm{z}$ obozów dla przesiedleńców. Przeżycia matki, robotnicy przymusowej z fabryki Rheinmetall Borsig w Unterluss, skłoniły ją do zajęcia się wzmiankowaną tematyką. Atutem tej pracy jest nie tylko wykorzystanie przez autorkę polsko-, niemiecko- i anglojęzycznej literatury przedmiotu, ale przede wszystkim bogata baza źród- 
łowa, na którą składają się m.in. dokumenty dotyczące robotników przymusowych, a także niezwykle liczne wspomnienia kobiet zgromadzone w Archiwum Narodowym w College Park, polskie czasopisma przechowywane w Bibliotece Kongresu, dokumenty wojenne (War Records) ze zbiorów Biblioteki Narodowej w Londynie, a także archiwalia Instytutu Pamięci Narodowej czy zbiory Freie Universität w Berlinie.

Książka podzielona jest na osiem rozdziałów, które przybliżają kolejne aspekty życia robotnic przymusowych. Treści merytoryczne uzupełniane są obszernymi, niekiedy bardzo osobistymi wspomnieniami. Nadaje to narracji interesujący i indywidualny charakter. Autorka z zauważalną starannością i dbałością o szczegóły przybliża czytelnikowi sytuację ludności polskiej na terytoriach okupowanych i wcielonych do Trzeciej Rzeszy.

W rozdziale pierwszym omówiono funkcjonowanie urzędów pracy, zagadnienie szeroko rozumianej rekrutacji, a także tzw. łapanek, organizowanych w Generalnym Gubernatorstwie.

$\mathrm{W}$ kolejnej części autorka przedstawia sytuację $\mathrm{w}$ obozach przejściowych, gdzie umieszczano robotników przymusowych w celu ich zewidencjonowania i pogrupowania przed wywiezieniem do Niemiec.

Samym transportom, ich warunkom oraz pierwszym dniom po przybyciu do miejsca przymusowej pracy, autorka poświęciła trzeci rozdział książki, w którym publikuje także wiele dyskryminacyjnych zarządzeń (tzw. dekretów polskich, nazywanych także marcowymi), wydanych w marcu 1940 r., mających na celu regulację warunków pracy i życia polskich robotników cywilnych.

W kolejnych dwóch ustępach publikacji Sophie Hodorowicz Knab podjęła się przybliżenia tematyki życia codziennego, pracy $\mathrm{w}$ rolnictwie i w fabrykach, a także warunków higienicznych, problemów zdrowotnych, hospitalizacji i eutanazji. Z pośród wielu przytaczanych przez autorkę interesujących aspektów warto chociażby wspomnieć o podejmowanych przez władze niemieckie próbach kształtowania postawy miejscowej ludności wobec robotników przymusowych. Starania te odzwierciedla opublikowane $\mathrm{w}$ książce memorandum przygotowane przez Biuro Propagandy w Oldenburgu, które zawierało wiele pouczeń, dotyczących kontaktów z Polakami.

O niezwykle ważnych kwestiach związanych z egzystencją pracownic przymusowych traktuje także rozdział szósty, zatytułowany Ciąża $i$ rodzenie dzieci $w$ nazistowskich Niemczech. Autorka opisuje w nim niezwykle trudną sytuację ciężarnych kobiet. Nie pomija w nim również problematyki napaści na tle seksualnym, molestowania, gwałtów, a także szeroko rozumianych kontaktów intymnych. Uwzględnia także kwestie badań rasowych i przymusowej aborcji. Na podstawie funkcjonowania 
poszczególnych placówek (m.in. domu dziecka w Vlepke, domu opieki dla obcokrajowych dzieci w Wolfsburgu, domu rodzącej matki dla cudzoziemek w Brunszwiku, a także domów matki i dziecka w Unterluss) opisuje dramatyczne losy dzieci robotnic przymusowych, które uznano za rasowo bezwartościowe. Ważnym elementem tego rozdziału są cytowane przez autorkę zarządzenia i dyrektywy, wydawane przez władze Trzeciej Rzeszy, które regulowały zasady postępowania z ciężarnymi robotnicami zagranicznymi.

Kolejna, przedostatnia część książki odnosi się do wydarzeń, do których doszło u schyłku II wojny światowej. Znajdujemy w niej informacje o zmianach zachodzących wówczas w egzystencji robotników przymusowych - pogłębiających się problemach aprowizacyjnych, braku kontaktów z rodzinami, kierowaniu do wyczerpującej pracy przy kopaniu rowów przeciwczołgowych czy odgruzowywaniu miast, a także bardzo napiętej i niepewnej atmosferze. W tym rozdziale Sophie Hodorowicz Knab przedstawia wydarzenia minionych dni także przez pryzmat przeżyć swojej matki, zabierając czytelnika niejako w wędrówkę jej śladem. Obszernie przytacza także dziennik Gabrieli Turnat, który stanowi skrupulatną, pełną emocji relację z ostatniego miesiąca pracy przed jej wyzwoleniem. Omówiona została również problematyka obozów dla osób wysiedlonych (DP), a także zagadnienia związane z repatriacją i imigracją.

Rozdział ósmy, zatytułowany Pokłosie, będący niejako epilogiem, poświęcono rozważaniom na temat psychicznej i emocjonalnej traumy, jaka dotykała robotników przymusowych. Sophie Hodorowicz Knab odnosi się tu także do bardzo osobistych doświadczeń, podkreślając, że jako dziecko nie mogła zrozumieć postępowania matki doświadczonej piętnem wojny. W swoich rozważaniach zwraca również uwagę, że robotnicy przymusowi przez długi czas nie mogli doczekać się statusu osób prześladowanych. Wskazuje, że ich historie nigdy nie wzbudzały tak dużego zainteresowania jak przeżycia ofiar obozów koncentracyjnych, a zatem często pozostawały na marginesie rozważań badaczy i historyków.

Książka Naznaczone litera P... nie jest sensu stricte publikacją o charakterze naukowym. Autorka w największym stopniu oddała głos bohaterkom tamtych czasów, tworząc niezwykle ciekawą narrację o ogromnym ładunku emocjonalnym, która jest zarazem niezwykle ważną formą upamiętnienia. Omawiana publikacja z pewnością zainteresuje szerokie grono odbiorców zajmujących się historią II wojny światowej. Może stać się ona także impulsem do podjęcia ponownych, kompleksowych badań nad sytuacją robotnic przymusowych w latach 1939-1945.

Wirginia Węglińska 